\title{
Europe tries again on biotechnology patents
}

Munich. As the European Patent Office (EPO) prepares to rule this week on a challenge to the patentability of Harvard University's 'oncomouse', the European Parliament has agreed to take part in a three-way discussion next January with representatives of the European Commission and the Council of Ministers on various issues relating to biotechnology, including new rules to harmonize patent legislation.

The draft rules are being drawn up by the commission, following the unexpected rejection of its previous proposals by the European Parliament last March, after they had been approved by the European Council of Ministers (see Nature 374, 103; 1995).

A broad political spectrum of parliamentarians joined their Green colleagues in rejecting the bill. In addition to the Greens' opposition to all patenting of any life forms on moral grounds, two other factors were cited. First, the draft directive did not protect the rights of farmers to breed from their own animals for their own purposes, known as 'farmers' privilege'. Second, many claimed that a lack of clarity in the text left too many loopholes through which individual member states could squeeze.

Christof Tannert, for example, a German member of the European Parliament (MEP), and speaker for the European Social Democrats on biotechnology, claims that the proposed text did not distinguish sufficiently clearly between a discovery and an invention. This would have allowed for a sort of 'biological colonialism', whereby industries in developed countries could patent newly discovered species of plants or animals in developing countries, he says. In addition, he expressed concern that the patenting of techniques for germ-line therapy was not explicitly excluded.

Commission officials admit that the draft text, the result of seven years of negotiation with both member states and the parliament, still contained some ambiguities, and has prepared a new version. This time, it has launched a broad campaign to increase the chances of its approval.

Over the past few months, for example, Mario Monti, commissioner for the internal market and industrial affairs, has consulted widely among parliamentarians and industry about whether the new text - which is not yet publicly available - will be acceptable. January's discussion meeting will be a final test of mood before the commission announces a formal decision to put the new

\section{Agronomist quits in funding protest}

Munich. A prominent French agronomist has resigned angrily from the committee responsible for a European programme in agriculture-related research in protest at what he claims to be excessive political interference in the allocation of funds.

Roger Cassini, director of the Parisbased Institut Nationale de la Recherche Agronomique, has resigned as French delegate to the programme committee of the European Commission's ECU600-million (US\$800-million) programme on fisheries and agro-industry research (FAIR), accusing the commission of having manipulated a list of successful grant applicants to ensure its approval by EU member states.

The commission itself has so far refused to comment on Cassini's resignation, which was triggered by a dispute over the distribution of ECU44 million which the commission had available for allocation to applicants responding to its first call for proposals for the FAIR programme, part of the fourth Framework programme.

Having sifted through nearly a thousand applications, almost half of which were judged by scientific reviewers as suitable for funding, an initial shortlist was drawn up by the commission's staff last month. But this was rejected by the programme committee, whose members are representatives of EU states, some of whom - particularly Italy, Spain and Greece - did not feel that their own scientists were fairly represented among the shortlisted applicants.

Faced with the prospect of losing the money unless an approved shortlist was adopted by the commission by the end of the year, the commission presented a revised shortlist to the programme committee last week. But it withdrew plans to put the list to the vote when it became clear that it was likely to be rejected again.

According to Cassini, the director of the committee then left the room with the delegates from Spain, Italy and Greece. He returned shortly afterwards with a revised list, with two additional projects added favouring these countries at positions which virtually guarantee funding. The three countries then announced their support for the revised list.

Cassini describes the commission's actions as "scandalous". A British delegate to the committee describes the meeting as chaotic, and claims that the dispute over the shortlist has highlighted the controversial role of national interests in allocating research funds. The commission does not have rules requiring it to achieve geographical balance in its programmes.

But another committee member, Christian Hubrich, of Germany's federal ministry of agriculture, says that at the same time the revision of the shortlist, while regrettable, did not infringe any rules. $A$. $A$. directive on the table.

Dominique Vandergheynst, the EC official who is the chief architect of the revised draft directive, says that the new text acknowledges a 'farmers' privilege', specifically excludes patents on germ-line gene therapy techniques, and distinguishes clearly between invention and discovery, with the latter excluded from patentability.

With these changes, Vandergheynst claims that most MEPs should find the new directive acceptable, predicting that its first parliamentary reading should be completed within a year. According to Vandergheynst the main thrust of what many considered the most controversial section - the one that covers the patenting of human genes remains unchanged from the earlier draft.

Thus genes in their natural state would be unpatentable. But isolated genes, when used diagnostically or as starting material for a biotechnological process, would be patentable. Transgenic animals would in principle be patentable, provided that their use for human well-being outweighs any suffering to the animal, as would plants, but not plant varieties.

The biotechnology industry, which has cooled on the need for a directive following the debacle in March, is now waiting with interest to see the new text in detail. Brian Yorke, head of the patent department at Sandoz, says that a good directive is needed to harmonize national patent laws, and to give a clear ruling on whether genes, plants and animals are patentable, as this remains ambiguous in the European Patent Convention. "Industry must know what the legal position on infringement in Europe is in this field," he says. He claims that the original, unsuccessful draft, was too unclear to be of significant benefit to industry.

Yorke says that he is very optimistic about the revision. But, like many in industry, he is concerned that further changes could be introduced during the lengthy 'co-decision' process under which all three European bodies - commission, council and parliament - must agree on all directives.

A spokesman for the European Federation of Pharmaceutical Industries puts it plainly: parliamentarians, who have considerable influence as a result of the co-decision process, may now be reassured, but are very unpredictable and may come up with new problems.

Furthermore, not all of industry is enthusiastic about a new directive. Jan Leemings, director of Plant Genetics Systems (PGS), argues that rulings on patent protection should be left to the EPO. He says that the EPO is already resolving the lack of clarity in the European Patent Convention by building up case law experience, and is concerned that a further layer of legislation could add new restrictions. Alison Abbott 